\title{
Prevalence of important zoonotic parasites in dog populations from the Slovak Republic
}

\author{
E. SZABOVÁ, P. JURIŠ, M. MITERPÁKOVÁ, D. ANTOLOVÁ, I. PAPAJOVÁ, H. ŠEFČÍKOVÁ
}

Parasitological Institute of the Slovak Academy of Science in Košice, Hlinkova 3, 04001 Košice, E-mail: eva.szabova@yahoo.com

\begin{abstract}
Summary
Dogs serve as the vectors of serious parasitic diseases with a zoonotic character. In a one-year-study, we collected and examined 752 faeces of dogs. In these faecal samples, 11 different species of intestinal endoparasites were detected, as follows: Toxocara spp. eggs $(21.9 \%)$, eggs from the family Ancylostomatidae (18.4\%), coccidia oocysts (10.4 $\%)$, eggs of Trichuris spp. (10.0\%), Toxascaris leonina (7.3\%), Capillaria spp. (5.9\%), Taenia type eggs (3.2\%) and Giardia spp. cysts (1.6\%). Echinococcus multilocularis was detected in one sample. Toxocara spp. eggs were dominant in all dog categories, but in hunting dogs they occurred at the highest rate $(45.1 \%)$. Faecal samples of dogs from rural ecosystems showed $66.0 \%$ prevalence of intestinal helminths. Presence of Toxocara spp. eggs was found in $25.0 \%$ of sand samples.
\end{abstract}

Key words: endoparasites; eggs; zoonosis; sandpits; contamination

\section{Introduction}

In human society, dogs play many roles such as pets, guarding, hunting and shepherding, and they are also used in therapeutic programmes, life saving actions, transport, and last but not least for fun and research. In some cultures, dogs serve as a food source. Moreover, in many cases a dog is a good companion, mainly for children and disabled people (Beck, 1979).

Due to the limited open green areas for a dog walking and a rising popularity of keeping dogs in urban agglomeration, their concentration increases in the public areas. Their excrements contaminate the environment and if these dogs are infected they are also a source of infection for other dogs, cats and animals (e. g. rodents).

A close contact between dogs and people increases the risk of transmission of different zoonotic diseases. Thoughtless dog breeding raises the number of stray and free-living dogs; e.g. in the USA, approximately $2-6$ million dogs are euthanised per year (Rowan, 1992). To observe and monitor the movements and feeding of stray dogs is not possible. Therefore, from the aspect of transmission of diseases in urban and rural habitats, they present a high risk factor. The risk of transmitting parasitic and other diseases increases with a more frequent contact of dogs with wild carnivores, e. g. foxes. Due to high population growth, foxes have been found not only in the rural environment and recreational areas, but also in suburbs and housing estates of cities. They contribute to the maintenance of circulation not only of parasitozoonoses but also of other parasitoses of carnivores (Antolová et al., 2004; Juriš, 2004; Miterpáková et al., 2005).

Dogs are vectors of various parasitic zoonoses. The causative agents of protozoonoses are Entamoeba histolytica and Giardia intestinalis. All of them produce the cysts which are excreted with the faeces. Giardia spp. does not have a specific host. It infects animal species such as domestic animals, wildlife and also humans. Dogs and cats could be infected with six genotypes of Giardia spp. whereby three of them could have a zoonotic character (Joachim \& Prosl, 2005). From the aspect of public health, serious helminths are: Toxocara spp., Ancylostoma spp., Uncinaria spp., Trichuris spp., Capillaria spp., Strongyloides spp., Echinococcus spp., Dypilidium spp. etc. (Hays, 1976; Sanin et al., 1994; Čatár \& Böhmer, 1998; Horák \& Scholz, 1998).

The developmental stages of the endoparasites (cysts, sporocysts, eggs, larvae) can survive in the environment for a long time and represent a risk factor for animals and also for the human population.

The aims of this study were as follows: to monitor the occurrence of the propagative stages of intestinal endoparasites in selected regions of Slovakia; and to reveal the extent of sand contamination with eggs of Toxocara 
spp. in children's sandpits in selected urban areas of Košice City.

\section{Material and Methods}

\section{Characterization of studied locality}

The Slovak Republic is situated in Central Europe in the northern pacific temperate zone with periodical changes of four seasons, temporarily influenced by continental and oceanic climates. The oceanic air brings rainfall and reduces temperature. An average annual temperature ranges from $5.5^{\circ} \mathrm{C}$ to $10{ }^{\circ} \mathrm{C}$. During the winter, a whole territory is usually covered with snow. According to Konček's classification, Slovakia is divided into three areas: warm, moderately warm and cold. Half of the country is taken up by the part of the Carpathian Mountains Arch. Towards the south of the Carpathian Mountains, there is the Panonian Basin, with the Danube River. Along the Danube River, the Danubian Plain is spreading and in the eastern part of the Republic, there is the East Slovak Plain. The altitude in Slovakia ranges between $94 \mathrm{~m}$ to $2655 \mathrm{~m}$ above sea level (Oravec, 2006).

\section{Coprological examination of faeces}

A total of 752 fecal samples of dogs with different utilization (pet dogs, guard-dogs, and hunting dogs, dogs from shelters and Centers for import/export of animals were examined. The faecal samples were collected from 8 districts of Slovakia (Košice, Michalovce, Trebišov, Zvolen, Martin, Poprad, Bardejov, Lučenec). The data on age, sex and utilization of dogs were obtained from owners using the questionnaires. Excrements from sheltered dogs were collected immediately after the catch, usually without a further identification of the animals.

In 2006, throughout April - November, dog excrements were also collected at random from the public areas of the cities of Košice and Bardejov. These samples were marked as unknown. After collection, faecal samples were stored at $4{ }^{\circ} \mathrm{C}$ and examined for the presence of propagative stages of endoparasites as soon as possible.

A flotation method with the Shaeter's flotation solution (specific gravity $1.3 \mathrm{~g} \cdot \mathrm{ml}^{-1}$ ) was used. A total of 3 grams of faecal sample were centrifuged with the water for $5 \mathrm{mi}$ nutes at $1200 \mathrm{rpm}$. After pouring out the supernatant, the Shaeter's flotation solution was poured into $2 / 3$ of the test tube with the sediment, stirred and centrifuged once again. After 5 minutes, the test tube was replenished with flotation solution until a meniscus formed and covered with cover glass. The cover glass was removed and put on the mount glass after an hour of egg flotation. Samples were examined under the light microscope. For the detection of Giardia oocysts the Faust flotation solution (specific gravity $1.18 \mathrm{~g} \cdot \mathrm{ml}^{-1}$ ) was used.

Positive samples were also examined quantitatively. According to Permin and Hansen, (1998) the Concentration McMaster technique was used. The number of eggs in 3 grams of faeces was determined in the McMaster counting chamber with $2 \times 0.15 \mathrm{ml}$ volume of chambers. The counted volume of $0.3 \mathrm{ml}$ faecal suspension represents $1 / 20 \mathrm{~g}$ faeces. The number of eggs per gram (EPG) of faeces was calculated by multiplication factor 20. Dogs were classified as positive, if the presence of eggs, oocysts or cysts of intestinal endoparasites in the sample was detected. Egg counts in sample were classified as low $(1-30$ EPG), middle (31 - 100 EPG) or high (over 100 EPG).

Samples with the presence of the Taenia type eggs $(n=25)$ were investigated for the presence of Echinococcus spp. coproantigen using commercial ELISA test kit (CHEKIT ${ }^{\circledR}$ - Echinotest, Dr. Bommeli, Switzerland). Samples with positive ELISA results were examined with the nested PCR (Dinkel et al., 1998) to detect strictly E. multilocularis DNA.

The examination of sand samples from sandpits

Sixty pooled sand samples from the children's sandpits were collected in different urban areas of Košice (courtyard, parks and playgrounds) by scheme displayed in Fig. 1. According to the conditions of sandpits' maintenance, quality of sand and fences, sandpits were classified as untreated and as treated. The sand samples were investigated according to Kazacos (1983). To $100 \mathrm{~g}$ of pooled sand samples, $100 \mathrm{ml}$ of water and $0.5 \mathrm{ml}$ of the Tween 40 was added and decanted for 10 minutes. Then the sample was sieved and replenished with $1000 \mathrm{ml}$ of water. After an hour of sedimentation, sand sample was centrifuged and then floated with Sheather's flotation solution as described above.

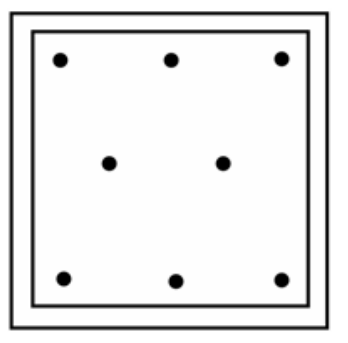

Fig. 1. Scheme of samples collection

Statistical methods

All data were analyzed with Chi - square test and Friedman test using STATISTICA 6.0 program (Statsoft, USA).

\section{Results}

Out of 752 dog faecal samples, 344 were positive for the presence of the propagative stages of endoparasites, representing the prevalence of $45.7 \%$. In the examined samples, 11 species of intestinal endoparasites were detected, in particular eggs of Toxocara spp. (21.9\%), the family Ancylostomatidae (18.4\%), coccidia oocysts (Isospora spp. and Sarcocystis spp.) (10.4\%), Trichuris spp. (10.0\%), Toxascaris leonina (7.3\%), Capillaria spp. (5.9\%), Taenia type eggs $(3.2 \%)$ and Giardia spp. cysts (1.6\%). Occasionally, also eggs of Spirocerca lupi $(0.7 \%)$ and Hymenolepis spp. $(0.3 \%)$ were present.

The majority of dogs was infected by only one species of 
parasite $(27.7 \%)$. Mixed infection caused by 4,5 or 6 species were also recorded and in one sample 7 parasite species were observed. Total counts of eggs in faecal samples of individual parasites species are described in Table 1 .

Table 1. Egg burdens in examined faecal samples based on EPG or OPG count (\%)

\begin{tabular}{lccc}
\hline & low & middle & high \\
\hline Toxocara spp. & 11.3 & 3.5 & 8.9 \\
Toxascaris spp. & 4.1 & 1.1 & 1.2 \\
Trichuris spp. & 6.1 & 1.1 & 2.7 \\
Capillaria spp. & 3.6 & 1.2 & 0.9 \\
Ancylostomatidae & 10.9 & 2.7 & 5.2 \\
Taeniidae & 2.5 & 0.1 & 0.5 \\
coccidia oocysts & 5.6 & 1.3 & 3.5 \\
\hline Total positivity & $\mathbf{4 4 . 2}$ & $\mathbf{1 0 . 9}$ & $\mathbf{2 2 . 9}$ \\
\hline \multicolumn{4}{c}{ low - 1-30 EPG,OPG; middle -31-100 EPG,OPG; }
\end{tabular}

The occurrence of parasitic species is summarized in Table 2. In the region of Michalovce, Trebišov and Bardejov, an average parasite prevalence of $70 \%$ was recorded. Prevalence of endoparasites in samples from Poprad and Lučenec reached up to $100 \%$, but due to a small number of investigated samples (22), results could not be statistically evaluated.

All species of parasites were observed in every age cate-
Table 3. Analysis of the coprological results according to the age of dogs

\begin{tabular}{|c|c|c|c|}
\hline & \multicolumn{3}{|c|}{ Age categories } \\
\hline & $\begin{array}{c}\text { under } \\
6 \text { months } \\
(\mathrm{n}=139) \\
(\%)\end{array}$ & $\begin{array}{c}\text { 6-12 months } \\
(\mathrm{n}=48) \\
(\%)\end{array}$ & $\begin{array}{c}\text { over } \\
12 \text { months } \\
(\mathrm{n}=133) \\
(\%)\end{array}$ \\
\hline Toxocara spp. & $53.2 * *$ & 37.5 & 18.8 \\
\hline Toxascaris spp. & 3.6 & 6.3 & 5.3 \\
\hline Trichuris spp. & 7.2 & 18.8 & $27.1 * *$ \\
\hline Capillaria spp. & 2.8 & 10.4 & 16.5 \\
\hline Ancylostomatidae & 7.2 & 14.6 & 17.3 \\
\hline Taeniidae & 2.8 & 6.3 & 5.3 \\
\hline coccidia oocysts & $24.5 * *$ & 2.1 & 2.3 \\
\hline Giardia spp. & 0.7 & 4.2 & 3.0 \\
\hline Total prevalence & $71.2 *$ & 56.3 & 46.6 \\
\hline
\end{tabular}

sence of coccidia oocysts in dogs younger than 6 months was higher $\left(\mathrm{P}=0.0001 ; \chi^{2}=21.99\right)$ than in dogs older than 12 months. The genus Trichuris dominated in older dog populations, with significant association observed between the infection rate of age category over 12 months $(\mathrm{P}=$ $0.0002 ; \chi^{2}=13.62$ ). No significant association was observed between the prevalence of endoparasite eggs in males $(53.6 \%)$ and females $(60.8 \%)$.

Table 2. Presence of dog's endoparasites from selected areas of the Slovakia

\begin{tabular}{lcccccccc}
\hline & $\begin{array}{c}\text { Michalovce Trebišov } \\
(\mathrm{n}=99)\end{array}$ & $\begin{array}{c}\text { Košice } \\
(\mathrm{n}=83)\end{array}$ & $\begin{array}{c}\text { Poprad Bardejov } \\
(\mathrm{n}=250)\end{array}$ & $\begin{array}{c}\text { Lučenec Zvolen Martin } \\
(\mathrm{n}=10)\end{array}$ & $\begin{array}{c}(\mathrm{n}=106) \\
(\mathrm{n}=12)\end{array}$ & $(\mathrm{n}=61)$ & $(\mathrm{n}=131)$ \\
& $(\%)$ & $(\%)$ & $(\%)$ & $(\%)$ & $(\%)$ & $(\%)$ & $(\%)$ & $(\%)$ \\
\hline Toxocara spp. & 47.5 & 25.3 & 12.4 & 30.0 & 12.3 & 33.3 & 32.8 & 26.7 \\
Toxascaris spp. & 3.0 & 6.0 & 8.8 & 60.0 & 6.6 & 75.0 & 1.6 & 6.9 \\
Trichuris spp. & 10.0 & 37.3 & 6.0 & 0.0 & 1.9 & 75.0 & 13.1 & 12.2 \\
Capillaria spp. & 3.0 & 25.3 & 2.4 & 0.0 & 1.0 & 58.3 & 13.1 & 6.9 \\
Ancylostomatidae & 1.0 & 32.5 & 8.8 & 20.0 & 58.5 & 66.6 & 3.3 & 13.0 \\
Taeniidae & 2.0 & 20.5 & 2.4 & 0.0 & 1.9 & 25.0 & 1.6 & 6.9 \\
coccidia oocysts & 33.3 & 6.0 & 3.2 & 10.0 & 2.8 & 41.7 & 26.2 & 5.3 \\
Giardia spp. & 0.0 & 1.2 & 2.0 & 0.0 & 0.0 & 0.0 & 11.5 & 0.0 \\
Spirocerca lupi & 0.0 & 0.0 & 2.0 & 0.0 & 0.0 & 0.0 & 0.0 & 0.0 \\
Hymenolepis spp. & 0.0 & 0.0 & 0.8 & 0.0 & 0.0 & 0.0 & 0.0 & 0.0 \\
Heterakis galinae & 0.0 & 0.0 & 0.8 & 0.0 & 0.0 & 0.0 & 0.0 & 0.0 \\
\hline Total prevalence & $\mathbf{7 0 . 7}$ & $\mathbf{6 3 . 9}$ & $\mathbf{3 1 . 2}$ & $\mathbf{7 0 . 0}$ & $\mathbf{6 7 . 0}$ & $\mathbf{1 0 0 . 0}$ & $\mathbf{5 5 . 7}$ & $\mathbf{3 8 . 2}$ \\
$\mathrm{n}=$ number of examined samples & & & & & & &
\end{tabular}

gory of dogs, with a decreasing tendency depending on the age of animals (Table 3 ). The prevalence of endoparasite eggs in dogs younger than 6 months $(71.2 \%)$ was significantly higher $\left(\mathrm{P}=0.0407 ; \chi^{2}=4.19\right)$ than in dogs between 6-12 months and in dogs older than 12 months $(56.3 \%$ and $46.6 \%$, respectively). In examined dogs, the highest prevalence of the genus Toxocara was observed. Its occurrence decreased with the age of animals $(\leq 6$ months $=$ $53.2 \%, 6-12$ months $=37.5 \%, \geq 12$ months $=18.8 \%)$, with significantly higher prevalence in dogs under 6 months of age $\left(P=0.0001 ; \chi^{2}=16.6\right)$. Similarly, the pre-
According to utilization of dogs Toxocara spp. eggs were predominant in all dog categories, but in hunting dogs they occurred at the highest rate $(45.1 \%)$. In dogs from shelters, a high prevalence of Toxocara spp. (28.1\%) and Ancylostomatidae eggs (26.8\%) was found and dogs from Centres for import/export of animals were most frequently infected with Toxocara spp. (36.9\%) and coccidia (36.2 $\%$ ). In samples, collected at random from public areas (unknown individuals) the lowest prevalence (40.4\%) of endoparasites was recorded, with the eggs of Ancylostomatidae family being the most frequent $(25.6 \%)$. In 
pet dogs (kept in flats) the prevalence of parasites reached $54.5 \%$ (Table 4 ).

From different ecosystems in which dogs lived and moved, we divided animals into those coming from urban, suburban and rural areas. Totally $66.0 \%$ of dogs from rural ecosystem were infected with helminths or protozoa. A high percentage of infected individuals $(39.1 \%)$ was also ences of Toxocara spp. eggs presence between treated and untreated sandpits were not significantly important

\section{Discussion}

Many studies have revealed that toxocariasis is the most frequent parasitosis of dogs. Toxocara spp. is a common

Table 4. Presence of endoparasitic species in dogs with different utilization

\begin{tabular}{|c|c|c|c|c|c|c|}
\hline & $\begin{array}{c}\text { pet } \\
(\mathrm{n}=44) \\
(\%)\end{array}$ & $\begin{array}{l}\text { guard-dog } \\
\qquad(\mathrm{n}=41) \\
(\%)\end{array}$ & $\begin{array}{l}\text { hunting } \\
\begin{array}{c}(\mathrm{n}=51) \\
(\%)\end{array}\end{array}$ & $\begin{array}{l}\text { from Dog } \\
\text { Collection Centre } \\
(\mathrm{n}=130) \\
(\%)\end{array}$ & $\begin{array}{l}\text { from shelte } \\
\qquad \begin{array}{c}(\mathrm{n}=164) \\
(\%)\end{array}\end{array}$ & $\begin{array}{l}\text { unknown } \\
(\mathrm{n}=297) \\
(\%)\end{array}$ \\
\hline Toxocara spp. & 27.3 & 24.4 & 45.1 & 36.9 & 28.1 & 6.0 \\
\hline Toxascaris spp. & 9.1 & 9.8 & 9.8 & 0.0 & 5.0 & 8.0 \\
\hline Trichuris spp. & 25.0 & 19.5 & 27.5 & 1.5 & 19.5 & 1.4 \\
\hline Capillaria spp. & 9.1 & 14.6 & 4.0 & 3.1 & 14.1 & 1.7 \\
\hline Ancylostomatidae & 6.8 & 17.1 & 15.7 & 0.0 & 26.8 & 25.6 \\
\hline Taeniidae & 2.3 & 4.9 & 2.0 & 0.8 & 6.7 & 2.7 \\
\hline coccidia oocysts & 0.0 & 4.9 & 0.0 & 36.2 & 11.0 & 3.7 \\
\hline Giardia spp. & 0.0 & 0.0 & 0.0 & 0.0 & 4.3 & 1.7 \\
\hline Spirocerca lupi & 0.0 & 0.0 & 0.0 & 0.0 & 0.0 & 1.7 \\
\hline Hymenolepis spp. & 0.0 & 0.0 & 0.0 & 0.0 & 0.0 & 0.7 \\
\hline Heterakis gallinae & 0.0 & 0.0 & 0.0 & 0.0 & 0.0 & 0.7 \\
\hline Total prevalence & 54.5 & 54.5 & 70.6 & 60.0 & 60.4 & 40.4 \\
\hline
\end{tabular}

found in urban areas. In rural ecosystems, the presence of infected dogs was significantly higher $\left(\mathrm{P}=0.0492 ; \chi^{2}=\right.$ 3.87) than in those from suburban areas (Table 5).

From 25 faecal samples positive to Taenia type eggs only one sample was positive for the presence of Echinococcus spp. copro-antigens. In this sample, occurrence of Echinococcus multilocularis DNA was confirmed by the nested PCR method.

\begin{tabular}{|c|c|c|}
\hline Ecosystems & $\mathbf{n} / \mathbf{p}$ & $\%$ \\
\hline urban & $64 / 25$ & 39.1 \\
\hline suburban & $19 / 4$ & 21.1 \\
\hline rural & $44 / 29$ & $66.0 *$ \\
\hline Total positivity & $127 / 58$ & 45.7 \\
\hline
\end{tabular}

The high prevalence of canine endoparasites presents a risk factor for dissemination of parasitic propagative stages into the environment, and therefore we also monitored contamination of sandpits. Totally 60 sand samples were collected from the children's sandpits of Košice, from areas with frequent movement of dogs and examined for the presence of the parasites. The presence of Toxocara spp. eggs was found in $28.3 \%$ of sand samples. In untreated sandpits $39.4 \%$ prevalence of the propagative stage of the parasites was recorded, compared with treated sandpits in which only $14.8 \%$ positivity was observed. The differ- parasite of young dogs that predominantly occurs in animals younger than one year (Scothorn et al., 1965). In Poland, similarly to our results, a high prevalence of this parasite was recorded in dogs younger than 3 months (58.1 $\%$, while in older dogs only $2.5 \%$ prevalence was found (Luty, 2001). Habluetzel et al. (2003) detected $33.6 \%$ prevalence of Toxocara spp. eggs in Italy with higher occurrence in younger than older dogs. Similar results were achieved by Rubel et al. (2003) who recorded $60 \%$ prevalence of $T$. canis in dogs younger than one year in Buenos Aires, Argentina, compared with older dogs with positivity of $3 \%$. They also detected more frequent presence of $T$. canis eggs in female dogs $(22 \%)$ than in male dogs $(3 \%)$. Presence of the toxocariasis in young animals can be associated with specific behavior of larvae in host tissues (Luty, 2001). In female dogs, hormonal stimulation during gravidity supports transplacental migration of Toxocara larvae into the fetus (Oldham, 1965; Jacobs, et al., 1977). This migration, together with lactogenic transmission of larvae is the main source of infection of puppies (Kozák, 1998; Rubel et al., 2003). Authors (Greve, 1971; Turner and Pegg, 1977; Oliveira - Sequeira et al., 2002; Deutz et al., 2005) suggested that relationship between $T$. canis infection and increasing age-achieved immunity in adults could exist.

Rubel and Wisnivesky (2005) from Buenos Aires, besides Toxocara spp. eggs, also diagnosed eggs of Ancylostoma spp. and Trichuris spp. in dog faeces from two socio-economically different areas of town. Percentages of the infected dogs ranged between $40 \%$ and $70 \%$ and higher 
prevalence of both parasites was detected in areas with lower socio-economic level. Aguilar et al. (2005) in Mexico City found in dog faeces 9 parasitic species with the most frequent presence of $A$. caninum. In their study, in dogs younger than 9 months $T$. canis prevailed, while in dogs between 10 months and 6 years, Ancylostoma spp. and in older dogs Dipylidium caninum were dominant species. A. duodenale is important human parasite with zoonotic potential, especially in exposed regions (Brooker et al., 2004). It frequently occurs in summer when animals are concentrated in small areas with moist ground. Ancylostoma spp. causes infection after the invasion of infectious larvae through the skin (larva migrans cutanea) or by ingestion of eggs. Increased incidence of human infection with Trichuris spp., Ancylostoma spp. or Uncinaria spp. was recorded in subtropical and tropical areas presence, especially with low socio-economic level. Presence of the endoparasites found in our study demonstrates a possible risk of human infection in our conditions.

Sager et al. (2006) detected $26.9 \%$ presence of intestinal helminths in dog faecal samples from rural areas and only $16.6 \%$ prevalence in dogs from an urban environment. Similar results were obtained in Germany, where Knaus and Betke (1986) found a higher prevalence of T. canis eggs in rural dogs $(25.5 \%)$ than in urban ones $(15.2 \%)$. Habluetzel et al. (2003) in Italy determined the presence of Toxocara eggs in half of examined dogs originated from the rural areas, while only quarter of dogs from the city was infected.

In 2004, monitoring of the occurrence of helminths in dog faecal samples from Slovakia (Košice and Prešov district) was carried out by Antolová et al. (2004). They found 16.6 $\%$ prevalence of $T$. canis eggs, which were frequently detected in faecal samples of stray dogs $(32.1 \%)$. In our study, we observed a $28.1 \%$ prevalence of Toxocara spp. in stray dogs. In hunting dogs, the highest prevalence of the parasitic stages $(70.6 \%)$ with frequent prevalence of Toxocara spp. (45.1\%) was recorded. This is probably due to free movement of these dogs in the environment contaminated with faeces of wild animals (foxes). Consumption of small mammals or wastes from dead and killed wild-boars (paratenic hosts); whose role in the circulation of Toxocara spp. was confirmed by Antolová et al. (2006); can be another source of infection.

Stray dogs usually do not undergo parasitological treatment and deworming, and therefore they are possible carriers of many diseases. The high prevalence of parasites in Centres for import/export of animals could be influenced by neglected hygienic and veterinary care by breeders or by predominantly catching stray dogs. Low prevalence of endoparasites in samples collected at random probably related to keeping majority of dogs in flats. Presumably, these dogs are subjected to better hygienic and veterinary care in comparison with dogs from shelter and Centres for import/export of animals. The difference between the occurrences of propagation stages of parasites in dog groups with different social utilization was not statistically significant. A high positivity of pet dogs can be associated with transmitting parasitic germs by small mammals. During walking, pet dogs can have a contact with the small animals (or their faeces) and with insects too, which can be intermediate or paratenic hosts of endoparasites. Hymenolepis spp. eggs and Spirocerca lupi eggs found in the dogs' faeces from Košice are associated with this possibility. Eggs of these parasites can only pass through the intestine of dogs and be excreted in faeces. Detection of Heterakis gallinae eggs in dog faeces from the Centres for import/export of animals in Zvolen was noteworthy. We presume that they were infected with these eggs when feeding on poultry faeces, intestines or poultry wastes.

Recent studies have shown the presence of E. multilocularis in all districts of Slovakia, with high endemic foci with an estimated prevalence of more than $60 \%$ in northern parts of country (Miterpáková et al., 2006). The presence of this parasite in dog populations is an important fact from the view of public health. In humans, E. multilocularis can cause alveolar echinococcosis, which if not treated, may cause death. Infection can occur after ingestion of eggs from contaminated water, food or after a direct contact with dog (eggs on hair) (Macpherson and Craig, 2000).

High prevalence of Toxocara spp. eggs and eggs of other intestinal helminths (Toxascaris leonina, Trichuris spp., Capillaria spp., Ancylostomatidae and Taeniidae family, Isospora spp., Giardia spp. etc.) in dog populations pointed to the contamination of the environment, in which animals move. Some studies showed high contamination of the soil in parks (10-30\%), playgrounds, sandpits and other public spaces with eggs of Toxocara spp. (Gillespie et al., 1987).

Toxocara eggs at the time of excretion into the environment are non - embryonated, so they are not infective. They develop into the infective stage after $3-6$ weeks, depending on climatic and soil conditions (temperature, moisture), and in the environment they can survive for more than one year (Bruňanská et al., 1995; Overgaauw, 1997). Therefore the problem of toxocariasis is important mainly in the cities, where dogs are commonly walked in public areas. Contamination of the environment, with developing stages of helminths, potentially able to threaten the human health, is an important problem from the aspect of hygiene and the public health service. Parks and other public areas are important areas for transmission of parasitic diseases from environment to humans (Ó Lorcain, 1994; Schottler, 1998).

Conde Garcia et al., (1989) in Spain found higher contamination of soil with Toxocara spp. eggs in rural ecosystems $(9 \%)$ than in urban areas $(3.7 \%)$. High contamination of public playgrounds and parks was recorded in Ancona, Italy (Giacometti et al., 2000) and in Spain (Ruiz de Ybanez et al., 2001) in Mercia City, $64 \%$ and $67 \%$, respectively. Results of the examination of soil samples showed $30.6 \%$ prevalence of Toxocara spp. eggs in the public parks of Ankara, Turkey (Oge and Oge, 2000). On the contrary, in the year 2000, Mizgajska (2001) in Krakow region of Poland observed $30 \%$ contamination of 
soils, with higher presence of positive samples in the centre of city than in its surrounding.

Dog excrements in the grass, on the pavements, in the playgrounds and in sand present not only aesthetic problems, but it is also problem of hygiene and epidemiology. Beside parks and playgrounds also children's sandpits, which are frequently preferred places for dog and cat defecation, present a high risk of spread of parasitic diseases. In many countries the presence of the parasitic propagation stages in sandpits was observed. Horn et al. (1990) recorded $63.5 \%$ prevalence of parasites in playgrounds in Hannover and $30 \%$ of sandpits were contaminated with Toxocara spp. eggs. Valkounová (1982a,b), who monitored the contamination of sandpits with parasite eggs and oocysts in Prague, recorded the presence of intestinal helminths eggs in $35 \%$ of sand samples, but only $3.2 \%$ of faecal samples from given area were positive for $T$. canis eggs.

Many studies have shown the variability of prevalence of parasite species in faecal and soil (sand) samples. This variability is often influenced by a character of human population, its socio-economic and ethnic habits and also environmental conditions (climate). These factors to a great extend influence epidemiology of the infections (Conde García et al., 1989).

In conclusion, the presence of intestinal parasites found in our study confirmed the high risk of human infection with parasitozoonoses. These results indicate the necessity of the veterinary care for dogs and also the need of control and hygienic measures for dog owners. Decrease in numbers of stray animals in urban and rural areas can help to control the risk of parasitic zoonoses transmission. Similarly, covering of sandpits to prevent entry of dogs and cats, creating special areas for dog walking and removing excrements can decrease a potential risk of transmission of parasitic diseases between animals and people.

\section{Acknowledgement}

The authors wish to thank the staff of Centres for import/export of animals, Shelters for abandoned animals and Quarantine Clinic in Martin, Zvolen, Lučenec, Poprad, Košice, Trebišov. Study was financed by the Slovak Grant Committee VEGA, Grant No. 02/7190/27 and partially financed by Science and Technology Agency contract No. APVV-51-027605.

\section{References}

Aguilar, E. P., Cruz-Reyes, A., Martínes-Maya, J. J. (2005): Ecological analysis and description of the intestinal helminths present in dogs in Mexico City. Vet. Parasitol., 127: $139-146$

Antolová, D., ReiterovÁ, K., MiterpákovÁ, M., StAnKo, M., DubinskÝ, P. (2004): Circulation of Toxocara spp. in suburban and rural ecosystems in the Slovak republic. Vet. Parasitol., 126: $317-324$

AntolovÁ, D., ReITEROVÁ, K., DuBinskÝ, P. (2006): The role of wild boars (Sus scrofa) in circulation of trichinellosis, toxocarosis and ascariosis in the Slovak Republic. Helminthologia, 43 (2): 92 - 97

BECK, A. M. (1979): The impact of the canine - waste law. Environment, 21: 29 - 31

Brooker, S., Bethony, J., Hotez, P. J. (2004): Human hookworm infection in the 21 st Century. Adv. Parasitol., 58: $198-263$

BruñANSKÁ, M., DubinskÝ, P., REITEROVÁ, K. (1995): Toxocara canis: ultrastructural aspects of larval moulting in the maturing eggs. Int. J. Parasitol., 25 (6): $683-690$

Conde García, L., Alvarez, A. M., Martin, F. S. (1989): Epidemiological studies on toxocariasis and visceral larva migrans in zone of western Spain. Ann. Trop. Med. Parasitol., 83: $615-620$

ČAtÁr, G., BÖhmer, D. (1998): Med. Parasitol., Prague, BON-BON, 163, ISBN 80-902483-0-6

Deutz A., Fuchs, K., Auer, H., Krbl, U., Aspock, H., Kofer, J. (2005): Toxocara - infestations in Austria: a study on the risk of infection of farmers, slaughterhouse, staff, hunters and veterinarians. Parasitol. Res., 97 (5): 390 $-394$

Dinkel, A., von Nickisch RosenegK, M., Bilger, B., MERLI, M., LucIUS, R. AND ROMIG, T. (1998): Detection of Echinococcus multilocularis in the definitive host: coprodiagnosis by PCR as an alternative to necropsy. $J$. Clin. Microbiol., 36: $1871-1876$

Giacometti, A., Cirioni, O., Fortuna, M., Osimani, P., Antonicelli, L., Del Prete, M. S., Riva, A., D'Errico, M. M., Petrelli, E., Scalise, G. (2000): Environmental and serological evidence for the presence of toxocariasis in the urban area of Ancona, Italy. Eur. J. Epidemiol., 16: $1023-1026$

GILLESPIE, S. H. (1987): Human toxocariasis, a review. J. Appl. Bacteriol., 63: 473 - 479

GREVE, J. H. (1971): Age resistance to Toxocara canis in ascarid-free dogs. Am. J. Vet. Res. 32: $1185-1192$

Habluetzel, A., Traldi, G, Ruggieri, S., Attili, A. R., Scuppa, P., MARchetti, R., Menghini, G., Esposito, F. (2003): An estimation of Toxocara canis prevalence in dogs, environmental egg contamination and risk of human infection in the Marche region of Italy. Vet. Parasitol., 113: $243-252$

HAYS, B. D. (1976): Potential for parasitic disease transmission with land application of sewage plant effluents and sludges. Water Res., 11: 583 - 595.

HorÁK, P., SchOlZ, T. (1998): Helminths biologie, (Eds): Univerzity Karlovy - Karolinum, Prague, 139, ISBN 807184-782-8.

Horn, K., Schnieder, T., Stoye, M. (1990): Contamination of public children's playgrounds in Hanno-ver with helminth eggs. Dtsch. Tierarztl. Wochenschr., 97 (3): 122

Jacobs, D. E., PegG, E. J., Stevenson, P. (1977): Helminths of British dogs: Toxocara canis - a veterinary perspective. J. Small Anim. Pract., 18: 79 - 92

JOACHIM, A., Prosl, H. (2005): Giardiose: altes oder neues Problem? Vet. J., 12: $18-20$

JURIŠ, P., (2004): Epidemiology and profylaxy of helmin- 
tozoonoses on inhabitants originated from Slovak Republic, Habilitation work, Department of public health and social-work, University of Trnava, Kosice.

KAZACOS, K. R. (1983): Improved method for recovering ascarid and other helminth eggs from soil associated with epizootics and during survey studies. Am. J. Vet. Res., 44: $896-900$

KNAUS, B. U., BETKE, P. (1986): Larva migrans visceralis - occurence of Toxocara canis in dogs in the East German district of Cottbus. Angew. Parasitol., 27: 169 - 173

KozÁK, M. (1998): Internal diseases of dogs and cats. Prešov, (Eds) M\&M s. 439, ISBN 80-88950-00-7

LUTY, T. (2001): Prevalence of species of Toxocara in dogs, cats and red foxes from the Poznan region, Poland. $J$. Helminthol., 75: $153-156$

MAcPherson, C. N. L., CRAIG, P. S. (2000): Echinococcus spp. Macpherson, C. N. L. - Muslin, F. X. - Wandeler, A. I. Eds.: Dogs, Zoonoses and Public Health. CABI Publishing, Oxon, $213-222$.

MiterpákOVÁ, M., AntolovÁ, D., VÁrady, M., DUBINSKÝ, P. (2005): Parasitofauna of red foxes in Slovak Republic. Slov. Vet. Čas., 3: $168-170$

MiterpákovÁ, M., AntolovÁ, D., ŠEvČíkovÁ, Z., Stanko, M., Dinkel, A., GAŠPAR, V., DubinskÝ, P. (2006): Echinococcus multilocularis in musk rat (Ondatra zibethicus): the first finding of the parasite in naturally infected rodent in the Slovak Republic. Helminthologia 43 (2): $76-80$

MizgAJSKA, H. (2001): Eggs of Toxocara spp. in the environment and their public health implication. J. Helminthol., 75: $147-151$

OGE, H., OGE, S. (2000): Quantitative comparison of various methods for detecting eggs of Toxocara canis in samples of sand. Vet. Parasitol., 92: 75 - 79

OLDHAM, J. N. (1965): Observations on the incidence of Toxocara and Toxascaris in dogs and cats from the London area. J. Helminthol., 39: 251 - 256

Oliveira-Sequeira, T. C., Amarante, A. F., Ferrari, T. B., Nunes, L. C. (2002): Prevalence of intestinal parasites in dogs from Sao Paulo State. Brazil Vet. Parasitol., 103: $19-27$

Ó LORCAIN, P. (1994): Prevalence of Toxocara canis ova in public playgrounds in the Dublin area of Ireland. $J$. Helminthol., 68: $237-241$

ORAVEC, D.: http://www. fpv.umb.sk/ oravec/prednaska912-KlG.pdf - Climatic Classifications. Climegeography of Slovakia and Europe.).
OvergaAuw, P. A. M. (1997): Aspect of Toxocara epidemiology: Toxocariosis in dogs and cats. Crit. Rev. Microbiol., 3 (23): 233 - 251

Permin, A., Hansen, J. W. (1998): The epidemiology, diagnosis and control of poultry parasites, FAO-Animal Health Manual No.4, Food\&Agriculture Organization of the United, ISBN-10:9251042152, 168

RowAN, A. N. (1992): Shelters and pet overpopulation, statistical black hole. Anthrozoös, 5: 140 - 143

Ruiz de Ybanez, M. R., Garijo, M. M., Alonso, F. D. (2001): Prevalence and viability of eggs of Toxocara spp. and Toxascaris leonina in public parks in eastern Spain. $J$. Helminthol., 75: $169-173$

RuBEL, D., WISNIVESKY, C. (2005): Magnitude and distribution of caníne fecal contamination and helminth eggs in two areas of different urban structure, Greater Buenos Aires, Argentina. Vet. Parasitol., 133 (4): 339 - 347

Rubel, D., Zunino, G., SAntillán, G., Wisnivesky, C. (2003): Epidemiology of Toxocara canis in the dog population from two areas of different socioeconomic status, Greater Buenos Aires, Argentina. Vet. Parasitol., 115: 275 $-286$

Sager, H., Steiner Moret, CH., Grimm, F., Deplazes, P., Doherr, M. G., Gottstein, B. (2006): Coprological study on intestinal helminths in Swiss dogs: temporal aspects of anthelminthic treatment. Parasitol. Res., 98 (4): $333-338$

Sanin, D. F., Vesilind, A. P., Martel, J. C. (1994): Pathogen reduction capabilities of freeze/thaw sludge conditioning. Water Res., 28(11): 2393 - 2398

Scothorn, M. W., Koutz, F. R., Groves, H. P. (1965): Prenatal Toxocara canis infection in pups. J. Am. Vet. Med. Assoc., 146: $45-48$

SCHOTTLER, G. (1998): Studie zum vorkommen von wurmeiern - insbesondere von eiern des hundespulwurmes (Larva migrans visceralis-Syndrom) im strandsand von Warnemunde. Gesundheitswesen, 60: 766 - 767

Turner, T., PEGG, E. (1977): A survey of patent nematode infestation in dogs. Vet. Rec., 100: $284-285$

VALKOUNOVÁ, J. (1982a): Parasitological investigation of children's sandboxes and dog faeces from public areas of housing developments in Prague. Folia Parasitol., 29: 133 $-138$

VAlKounOVÁ, J. (1982b): Contamination of child's sandpits with parasitic eggs and oocysts especially by Toxocara in Prague area. Čsl. Epidemiol. Mikrobiol. Imunol., 31 (4): $232-235$ 